\title{
Effects of Fruit and Vegetable-Based Nutraceutical on Cognitive Function in a Healthy Population: Placebo-Controlled, Double-Blind, and Randomized Clinical Trial
}

\author{
Juan Ángel Carrillo (D), Raúl Arcusa, María Pilar Zafrilla * (D) and Javier Marhuenda \\ Faculty of Health Sciences, Universidad Católica de San Antonio, 30107 Murcia, Spain; \\ jacarrillo4@alu.ucam.edu (J.Á.C.); rarcusa@ucam.edu (R.A.); jmarhuenda@ucam.edu (J.M.) \\ * Correspondence: mpzafrilla@ucam.edu; Tel.: +34-968-27-86-18
}

check for updates

Citation: Carrillo, J.Á.; Arcusa, R.; Zafrilla, M.P.; Marhuenda, J. Effects of Fruit and Vegetable-Based Nutraceutical on Cognitive Function in a Healthy Population: Placebo-Controlled, Double-Blind, and Randomized Clinical Trial. Antioxidants 2021, 10, 116. https://doi.org/10.3390/ antiox10010116

Received: 10 December 2020 Accepted: 12 January 2021 Published: 15 January 2021

Publisher's Note: MDPI stays neutral with regard to jurisdictional clai$\mathrm{ms}$ in published maps and institutional affiliations.

Copyright: $(\odot 2021$ by the authors. Licensee MDPI, Basel, Switzerland. This article is an open access article distributed under the terms and conditions of the Creative Commons Attribution (CC BY) license (https:// creativecommons.org/licenses/by/ $4.0 /)$.

\begin{abstract}
There is scientific evidence of the positive effect of polyphenols from plant foods on cognition, but not enough is known about the synergistic effect when multiple polyphenols are consumed and even less in a healthy non-elderly population. The aim of the present study is to investigate the possible effects of improvements in cognitive function in healthy people as a preparation based on micronized fruit and vegetables consumed. One hundred and eight subjects were selected, stratified by sex in the control intervention group $(n=53)$ and placebo $(n=55)$. Volunteers completed the study after two 16-week periods of consumption with a 4-week wash period between each phase. At the beginning and the end of each phase, volunteers performed the Stroop, TESEN, and RIST tests for the measurement of different cognitive function patterns. The results revealed statistically significant differences in all the variables of the tests carried out, especially compared with the placebo. Specially, the results obtained in the Stroop and TESEN test, in addition to the processing speed even with semantic interferences, were markedly better after the treatment with the product under study. Moreover, the consumption of the product under study clearly improves short-term memory, verbal and non-verbal, according to the results obtained in the RIST test. The results showed an improvement in executive function in terms of short-term memory, working memory, selective and sustained attention, and speed of processing.
\end{abstract}

Keywords: cognition; polyphenols; executive function; memory; attention; Stroop; TESEN; RIST

\section{Introduction}

Polyphenols, including phenolic acids, flavonoids, such as anthocyanins or flavonols and tannins, vary depending on the fruits or vegetables where they are present: berries, onions, apples, parsley, celery, broccoli... [1,2]. They have a considerable capacity to neutralize free radicals and exert anti-inflammatory and neuroprotective effects [3,4] and are considered important in cognitive function. Although the mechanisms of action have not yet been clarified, these compounds are known to modulate cerebral blood flow, inducing changes in memory processing [5,6], improving neuronal connectivity and neuronal growth in the hippocampus [7], and synaptic plasticity [8] related to variations in nitric oxide (NO) levels [9].

The effect of bioactive compounds also depends on consumption and frequency levels $[10,11]$ since there is evidence of the effects in acute consumption [12], but not so much in prolonged consumption over time. The brain is especially sensitive and prone to oxidative damage and the accumulation of reactive oxygen species (ROS) due to increases in oxygen consumption [13]. Polyphenol supplementation decreases the vulnerability of elderly people who present higher risk factors to oxidative stress, improving neuronal communicability [14,15].

There are authors who have investigated the synergistic effects of various plant compounds [16,17], but their effects have not been clearly demonstrated and more randomized 
trials are needed [12]. Some authors have shown that the consumption of a Mediterranean diet in young people leads to a decreased risk of dementia when they are elderly $[18,19]$, and that in these healthy young subjects improved mood and a decreased risk of depression has been noted [20]. Other authors have demonstrated an association between a diet that is high in fruit and vegetables with improvements in executive functions [21].

Cognitive functions can be evaluated through cognitive tests in combination with other interventions as functional MRI [22]. These tests are agreed by the scientific community and are used as evidence for certain healthy statements [23,24]. In order to reach an adequate consumption of polyphenols, nutraceuticals can provide an easy means of consuming an adequate allowance of polyphenols [25-27], even though information on intervention studies in humans in clinical conditions is lacking [28-30].

Fruit and vegetables must be precursors to a new generation of treatments of diseases through diet and lifestyle [31], by the consumption of nutraceuticals [32,33]. However, few randomized studies on the effects of polyphenols on memory and learning have been conducted in human models in non-elderly populations [34], concluding positive effects on this benefits in animal models with the use of foods rich in flavonoids, evaluating memory dosing blueberry [35], memory with green tea [36], and learning with gingko biloba [37]. The objective of the present clinical trial is to evaluate the efficacy of continuous consumption of an extract based on multiple fruits and vegetables versus placebo in the improvement of cognitive function in healthy volunteers on several aspects of executive function, memory, and attention.

\section{Materials and Methods}

\subsection{Experimental Design}

The present intervention study is a randomized, crossover, double-blind, sex-stratified, placebo-controlled clinical control trial to assess the effect of daily intake of an encapsulated fruit, vegetable, and berry juice powder concentrate (Juice Plus+ Premium ${ }^{\circledR}$, The Juice Plus Company ${ }^{\circledR}$, Collierville, TN, USA) on cognitive functions. The duration of consumption was two periods of 16 weeks with an intermediate washout period of 4 weeks, and a daily intake of one of the products randomly assigned (product or placebo) (Figure 1). Once the first period was over and after the 4-week washout period, the groups were crossed so that all participants consumed both the product and the placebo.

During the experimental phase, each subject made a total of four visits throughout the research period to performing the relevant cognitive tests (Table 1). The protocol of this research study was approved by the ethics committee of the Catholic University of Murcia (date: 24 November 2017; Code: CE111702). The study was carried out following the Standards of Good Clinical Practice and the conditions that should govern human research studies that are defined in the Declaration of Helsinki. Current European legislation on the protection of personal data was complied with (Regulation (EU) 2016/679).

Table 1. Follow-up actions at each unit visit.

\begin{tabular}{cccccc}
\hline Monitoring & VS & V1 & V2 & V3 & V4 \\
\hline Informed Consent & $\mathrm{X}$ & & & & \\
Inclusion/exclusion criteria & $\mathrm{X}$ & & & & \\
History, lifestyle, dietary and eating habits & $\mathrm{X}$ & & & & \\
Randomization & $\mathrm{X}$ & & & & \\
Product/placebo delivery & & $\mathrm{X}$ & & $\mathrm{X}$ & \\
performing cognitive tests & & $\mathrm{X}$ & $\mathrm{X}$ & $\mathrm{X}$ & $\mathrm{X}$ \\
\hline $\mathrm{V}=$ Visits to the research unit. VS = visit start. X = action completed at each unit visit. & &
\end{tabular}




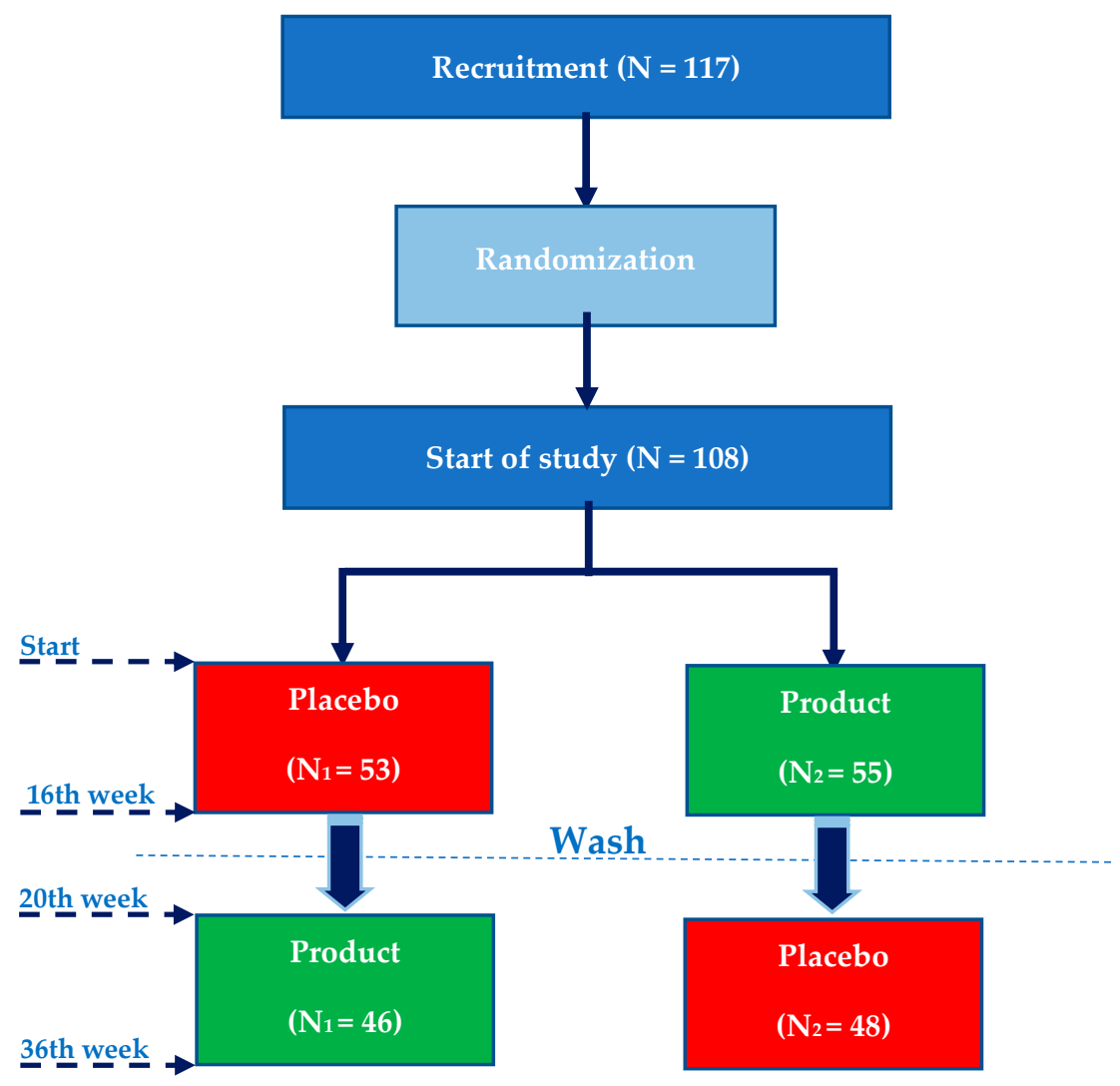

Figure 1. Phases of the intervention study. N1 = group 1 randomly selected. N2 = group 2 randomly selected.

\subsection{Study Population}

A total of 117 volunteers were selected by means of distribution by mail and posters among students and university staff to determine their participation in the study. Of them, 108 fulfilled the inclusion criteria. 16 volunteers were rejected since they no longer met the selected inclusion/exclusion criteria or refused to continue. The total number of subjects included in the study was 92 . Of these, 47 were male (51.09\%) and 45 were women $(48.91 \%)$. The mean age was $32.74 \pm$ years.

\subsection{Inclusion and Exclusion Criteria}

The volunteers had to meet the following inclusion criteria: signed informed consent; body mass index $\geq 18.5$ and $\leq 35 \mathrm{Kg} / \mathrm{m}^{2}$; not suffer from chronic illness; not consume more than three pieces of fruit or vegetables a day; and be between 18 and 65 years of age. The presence of at least one of the following criteria was a reason for exclusion from the clinical trial: being under medical or pharmacological treatment; having an allergy to fruit and/or vegetables; being on a diet; vegetarian or vegan; being a smoker; consuming more than 3 glasses of alcohol (wine or beer) a day; pregnancy; having undergone major surgery in the last 3 months; irregular or insufficient sleep; having donated more than $0.5 \mathrm{~L}$ of blood in the last month. To verify compliance with these requirements, the volunteers were interviewed, weighed and measured, and they filled out a questionnaire on lifestyle and nutrition habits used in previous studies [38] and by other authors [39].

\subsection{Tested Product}

The product tested contained a homogenized mixture of dehydrated juice and pulps of grapes and berries, fruits, and vegetables (56\%) in variable proportions of apple, carrot, concord grape, pomegranate, orange, pineapple, blueberry, lingonberry, bilberry American, blackberry, cabbage, garlic, myrtle, citrus, mango, raspberry, acerola, peach, date, parsley, broccoli, spinach, kale, tomato, elderberry, blackcurrant, plum, beet, coating agent (pullulan), cocoa powder, green tea extract, tocopherol blend, ginger root powder, calcium 
ascorbate, artichoke leaf extract, grape seed extract, rice bran, spirulina powder, anti-caking agent: silicon dioxide, magnesium salts of fatty acids, citrus extract, lutein, beta-carotene, lycopene, astaxanthin and maltodextrin. The mixture was encapsulated in a white pullulan capsule. Each package contained sufficient capsules for 4 months of consumption (each period of consumption) considering a dose of 6 capsules a day ( 3 in the morning with breakfast and 3 in the evening with dinner).

The polyphenolic characterization was performed with UHPLC-QqQ-MS, in a previous study in 2017 by Bresciani and col. The product showed a total of 119 polyphenolic compounds belonging to different phenolic families: flavonols, such as kaempferol and quercetin, anthocyanins, and flavones [40]. The daily consumption of 6 capsules used in this study is the usual consumption in other intervention studies that have been performed previously involving a total of $600 \mathrm{mg}$ of phenolic mixture [41-43]. The placebo was made of microcrystalline cellulose and had the same appearance and dosage as the product in order to avoid differentiation by the subjects or the research staff.

\subsection{Cognitive Tests}

To evaluate selective attention, the Stroop test was used [44]. This test has been used in studies in adults $[45,46]$ and even in children [47] and is widely used in clinical studies to evaluate the effects of flavonoids on memory and attention both in children and adults [48]. Volunteers have to read as many items as possible from three independent consecutive parts resulting in three scores: $P$ scores: number of words read on the page to read words, in which different colors appear written in one ink, C scores: number of items made on the name colors page, in which words written in different colors appear and the volunteers have to name the ink of the color with which they are written and PC scores: number of items made on the page of words-colors, in which you have to name the color of the ink with which the word is written, each word being a different color. The difficulty increases in each part, as there is semantic interference. Two methods are used for outcome measures: the time that the subject takes to complete 100 elements, and the number of elements completed in $45 \mathrm{~s}$.

Moreover, the TESEN test used in the present study (Test of the trail) was developed in Spain for the evaluation of executive functions and working memory and it is suitable for intervention studies with a healthy population [49]. It is an individual application test to assess the executive functioning of youth and adults using a visualmotor planning task. It permits evaluation of planning capacity, working memory, mental flexibility, alternation, sustained attention, prospective memory, the speed of perceptual processing and the fluidity of motor response.

It is made up of four tests (trails) of increasing difficulty. In the first, the subject must join the numbered points in ascending order. In the second, subjects must do the same process but in descending order. In the third path, the subject must join the numbers in increasing order alternating the color. In the fourth path, it is treated as in the case of the third but alternating geometric figures.

The test consists of three scores for each of the trails: Speed score (S): reflects the ability to solve tasks that require increasing attention and executive control; accuracy score or precision $(\mathrm{P})$ : reflects the number of hits and misses that the subject makes during the completion of each trail; and execution score (E): reflects the efficiency with which the evaluated person has carried out the task, taking into account speed and precision.

As a memory evaluation method, the RIST test (short adaptation of the RIAS test) [50], used in young people and children as an evaluation of working memory, was also performed in this study [51]. It consists of two tests: riddles and categories. The direct scores obtained are transferred to typical scores (TS) according to the scale table. The TSs are added up and the RIST index (RI) is calculated. 


\subsection{Statistic Analysis}

The Kolmogorov-Smirnov test was used to check for normal distribution of continuous data. This way, continuous variables were presented as mean \pm standard deviation (SD) in the baseline conditions and in their evolution. This analysis was performed for the total group of individuals who participated in the study in both the placebo and product consumption periods. The homogeneity of the population at baseline with respect to demographic variables, medical history and other clinical parameters were also analyzed. For the quantitative variables, $t$-Student comparisons were developed between the two branches of the study.

To analyze the differences between the groups (experimental and control) in the evolution of the different variables, an analysis of variance was performed for repeated measures with time as an intra-subject factor and product as an inter-subject factor. This way, differences in each analyzed variable were established, taking these factors into account. The Bonferroni test was performed for post-hoc analysis. Significant effects (with the option of assuming equality of variances or not) were compared. In the set of statistical tests, the significance level used was 0.05 . Statistical analysis was carried out with SPSS 24 computer software (SPSS, Inc., Chicago, IL, USA).

\section{Results}

\subsection{Stroop Test}

Table 2 shows the results along with the standard deviations of the number of words read $(\mathrm{W})$, the number of elements made on the name of colors page $(\mathrm{C})$, and the combination of words and colors (WC) in the initial and finals times for placebo and product. The results obtained in the three variables showed values above 30 in the typical scores (TS) in the initial times, with normal values for executive functions and attentional cognitive flexibility and with no neurological damage in any of the volunteers who underwent the tests. It was verified that there were differences in the three variables and that the subjects were able to read 4.2 more words in the first reading words test, to read 3.56 more words when it was about reading colors and also when there was semantic interference in the WC variable (4.67).

Table 2. Evolution of results obtained over time in Stroop test with product and placebo.

\begin{tabular}{cccc}
\hline & Stroop Test W & Stroop Test C & Stroop Test WC \\
\hline IPP & $46.12 \pm 7.60$ & $49.39 \pm 8.66$ & $49.40 \pm 8.68$ \\
FPP $^{2}$ & $45.86 \pm 6.06$ & $49.74 \pm 6.03$ & $50.96 \pm 6.61$ \\
IPPD $^{3}$ & $45.71 \pm 7.81$ & $49.07 \pm 8.63$ & $49.11 \pm 8.57$ \\
FPPD $^{4}$ & $49.91 \pm 7.05 *$ & $52.63 \pm 9.41 *$ & $53.78 \pm 7.79 *$ \\
\hline
\end{tabular}

IPP: Initial phase placebo. ${ }^{2}$ FPP: final phase placebo. ${ }^{3}$ IPPD: initial phase product. ${ }^{4}$ FPPD: final phase product Results expressed in typical score (TS), mean and standard error of mean. * There are statistically significant differences $(p<0.05)$ between IPPD and FPPD phases.

These differences were statistically significant $(p<0.01$ for W, C and for WC) and were not so in consumption of the placebo ( $p=0.783$ for $\mathrm{W}, p=0.744$ for $\mathrm{C}$ and for $p=0.166 \mathrm{WC})$. When comparing by sex, there were no differences in any of the tests carried out. The results obtained in the different variables of the Stroop test showed a clear improvement in the speed of processing and in the attention span of the subjects, comparing the product and the placebo intake (Figure 2). 


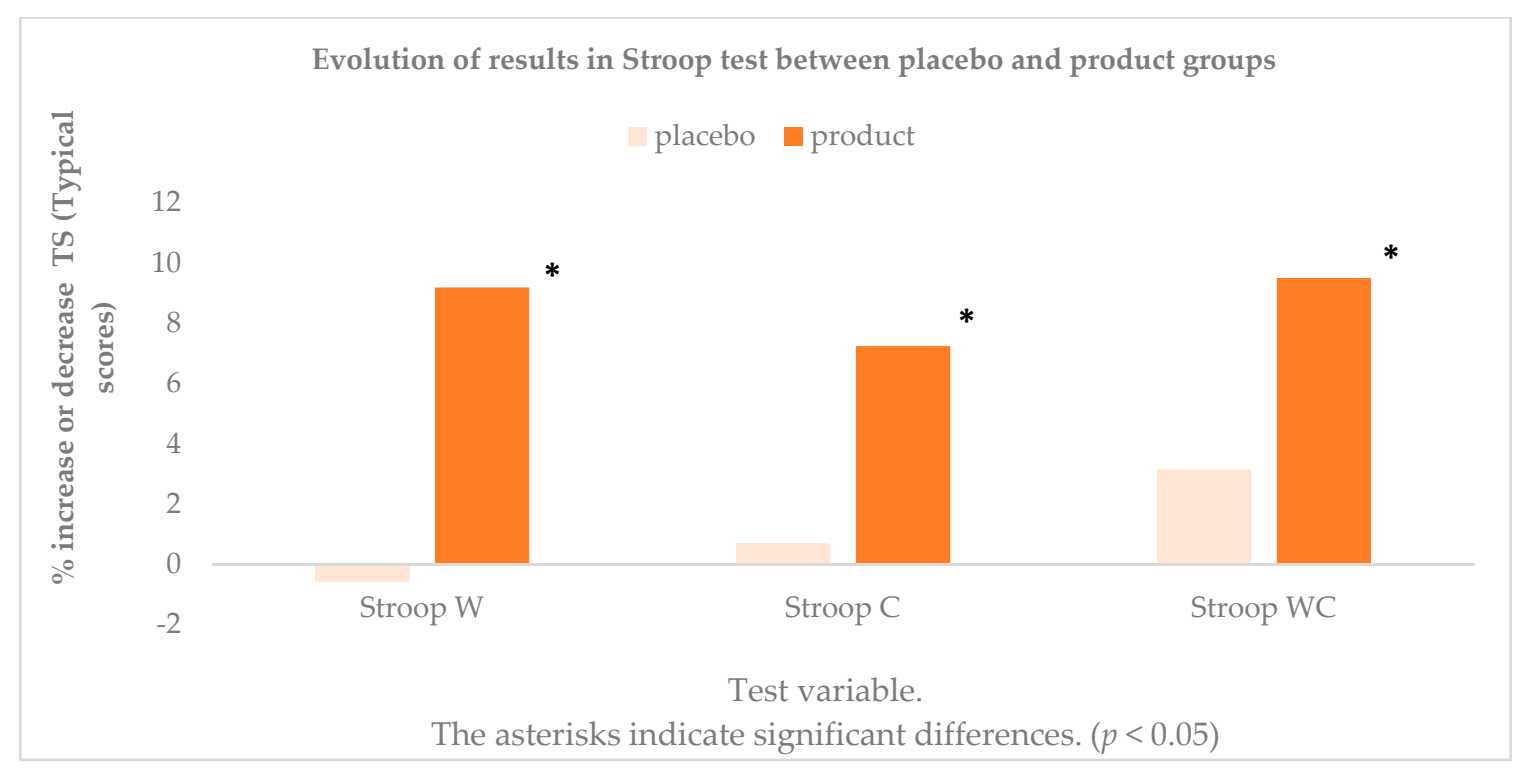

Figure 2. Evolution of results in the different variables of Stroop test in percentage increase or decrease. * indicate significant differences. $(p<0.05)$.

\subsection{TESEN Test}

As observed in the Stroop test, in the three variables measured in the TESEN test (trail test), significant differences were obtained in speed of execution (S), precision in terms of number of hits and misses $(\mathrm{P})$, and execution in relation to speed and precision in the execution (E) between the final and initial phases of consumption of product $(p<0.01)$, but not for the placebo $(p>0.05)$, as shown in Table 3 .

Table 3. Evolution of results obtained over time in TESEN test with product and placebo.

\begin{tabular}{cccc}
\hline & TESEN Test S & TESEN Test $P$ & TESEN Test E \\
\hline IPP & & & \\
FPP $^{2}$ & $402.28 \pm 53.32$ & $97.74 \pm 6.27$ & $19.88 \pm 4.18$ \\
IPPD $^{3}$ & $393.85 \pm 42.77$ & $98.25 \pm 9.03$ & $21.38 \pm 2.28$ \\
FPPD $^{4}$ & $406.83 \pm 54.05$ & $97.26 \pm 6.43$ & $19.69 \pm 4.10$ \\
\hline
\end{tabular}

${ }^{1}$ IPP: initial phase placebo. ${ }^{2}$ FPP: final phase placebo. ${ }^{3}$ IPPD: initial phase product. ${ }^{4}$ FPPD: final phase product. Results expressed in direct scores (DS), mean and standard error of mean. ${ }^{*}$ There are statistically significant differences $(p<0.05)$ between IPPD and FPPD phases.

The decrease in time in variable $\mathrm{S}$ showed a very marked decrease $(51 \mathrm{~s})$ when the product was consumed $(p<0.01)$ compared with the placebo $(p=0.25)$. In the case of variable $P$, the increase was 1.96 points of direct score (DS) after the consumption of the product $(p<0.01)$ versus the placebo $(p=0.68)$. There were no differences between sexes in any of the tests carried out. The scores obtained in all the variables of the tests performed improved when compared with the consumption of the placebo. The differences are statistically significant and, in some cases, very marked (Figure 3).

\subsection{RIST Test}

When comparing the results obtained in the scores of the RIST test, it was observed that there were differences between the initial and final phases in terms of product consumption. These differences were statistically significant $(p<0.01)$ but not so after placebo consumption $(p=0.30)$. Furthermore, in the case of product consumption, the differences between the final and initial phases were quite marked (15.27 points of difference in RI). When making the comparison differentiated by sex, there were no differences. The results are expressed in Table 4. As shown in Figure 4, the scores obtained in the RIST test im- 
proved when compared with the use of the placebo and there are statistically significant differences in RI.

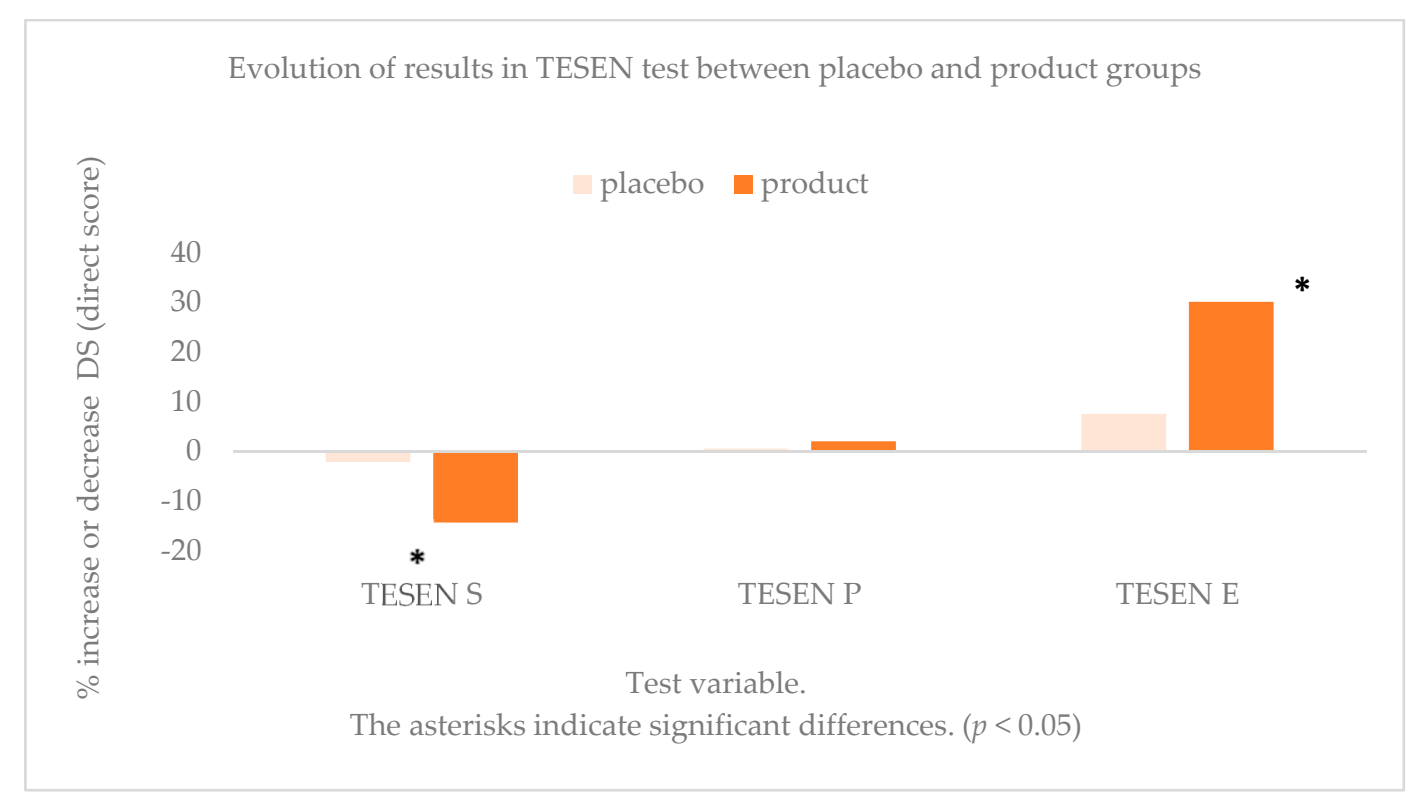

Figure 3. Evolution of results in the different variables of TESEN test in percentage increase or decrease. * indicate significant differences. $(p<0.05)$.

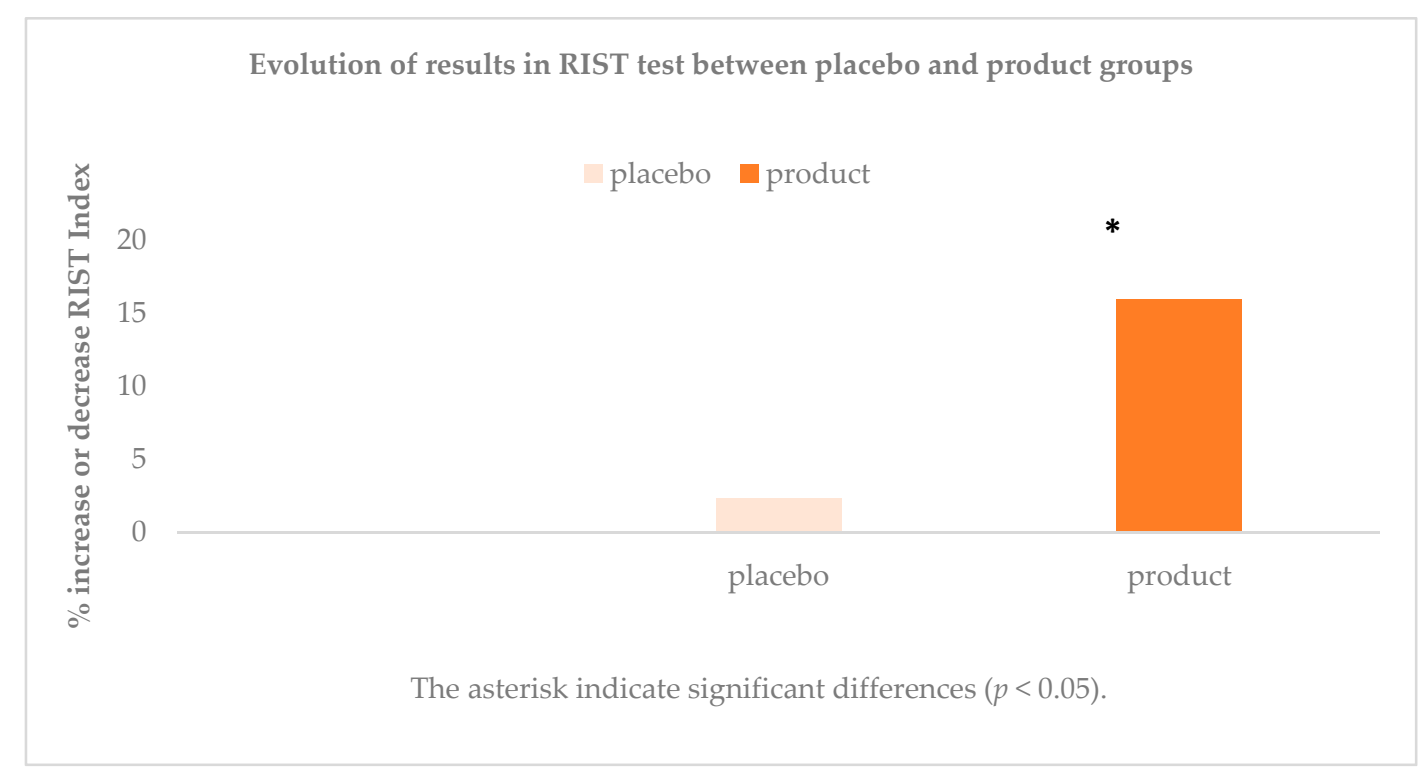

Figure 4. Evolution of results in RIST test between placebo and product groups in percentage increase or decrease. * indicate significant differences. $(p<0.05)$.

Table 4. Evolution of results obtained over time in RIST test with product and placebo.

\begin{tabular}{cc}
\hline & RIST Test \\
\hline IPP $^{1}$ & $95.91 \pm 16.24$ \\
FPP $^{2}$ & $98.19 \pm 13.82$ \\
$\operatorname{IPPD}^{3}$ & $95.59 \pm 16.35$ \\
FPPD $^{4}$ & $110.86 \pm 10.011^{*}$ \\
\hline
\end{tabular}

${ }^{1}$ IPP: initial phase placebo. ${ }^{2}$ FPP: final phase placebo. ${ }^{3}$ IPPD: initial phase product. ${ }^{4}$ FPPD: final phase product. Results expressed in RIST Index (RI), mean and standard error of mean. * There are statistically significant differences $(p<0.05)$ between IPPD and FPPD phases. 


\section{Discussion}

The purpose of the present study was to evaluate the efficacy of a fruit and vegetablebased extract versus placebo on cognitive function in healthy subjects in non-acute consumption. We hypothesized that an improvement could be achieved in accordance with previous studies although they were carried out in a population with neurodegenerative diseases or the polyphenolic extract used was not composed of a mixture of phenolic compounds $[11,52-56]$. The results obtained by other authors with different extracts followed a similar trend $[46,57,58]$, either using melon concentrate supplementation and its influence on psychological stress and mental fatigue, using the administration of soy isoflavones in elderly men evaluating the visual-spatial memory and verbal fluency in the subjects, or in the evaluation of the efficacy of Ginkgo biloba extract in people over 55 years of age, where improvements were obtained assessing the speed of processing skills. On the other hand, people with a diet pattern high in fruits and vegetables showed better cognitive results in the Stroop test compared with those with a less healthy diet pattern, 5 and 25 years later, as described in the results of a cohort study published in 2015 [40].

Other authors have evaluated executive functions using the Stroop test combined with diet and physical activity in patients with metabolic syndrome. In this case, this combination causes an improvement in executive function [59]. In the present study, the observed decrease of more than $50 \mathrm{~s}$ on average in the execution speed (S) of the trails in the product consumption period indicated a clear improvement in perceptual processing speeds and in fluidity in visual-motor response. The precision and efficiency in the achievement of the trails, with fewer errors, also indicated an improvement in executive functions such as the subject's capacity to plan, alternate and, ultimately, in the subject's working memory.

The results obtained with the TESEN test was to those reported by other authors previously in interventional studies with the execution of the trail making test (TMT), in people with mild cognitive impairment, showing improvement in cognitive functions [60]. In these studies, as in one carried out with the Norwegian elderly population, the consumption of several foods rich in flavonoids demonstrated not only an improvement in test scores, but also that this improvement was dependent on the dose and type of flavonoid [61]. The most pronounced cognitive improvements were reported for carrots, citrus, and crucifers.

In the case of the RIST test, the results of more than 15 points of difference in the RI when the product is consumed also coincide with the results obtained in the TESEN test in terms of working memory and with those obtained by other authors in similar intervention studies, using the RIST test in a danish cohort study with children [51], evaluation with RVIP test in the administration of an extract rich in polyphenols [12] concluding that its consumption can be an alternative for the improvement of working memory and attention and in other interventions using similar cognitive tests [17,62].

The results obtained in the different variables of the three tests used in this study, which show an improvement in cognitive functions, may be due to the role played by polyphenols in synaptic plasticity through the CREB protein and modulating pathways of signaling and transcription factors $[13,63,64]$. On the other hand, flavonoids especially anthocyanins, have a positive effect on the brain cells associated with memory and neuronal function, mainly due to the increase of cerebral blood flow [6,65-67].

\section{Conclusions}

Our data indicate that chronic consumption of a polyphenolic extract from fruits and vegetables over 4 months improves the processes involved in executive functions such as working memory (ability to plan, alternation and fluidity of the motor response) and short-term memory. All the variables of the Stroop and TESEN test have been significantly higher than those compared with placebo, in addition to the processing speed even when semantic interferences (WC) are present. On the other hand, according to the results obtained in the RIST test, consumption of the product clearly improves short-term memory, whether this is verbal or non-verbal. The product under study may represent an alternative 
system in the prevention of normal cognitive deterioration caused by age, through the consumption of fruit and vegetables, in addition to an improvement in cognitive functions (immediate and working memory, sustained, and selective attention).

Author Contributions: All authors J.Á.C., R.A., M.P.Z., J.M. designed and conducted the research, including sample analysis. All authors have read and agreed to the published version of the manuscript.

Funding: This research was funded by The Juice Plus Company LLC.

Institutional Review Board Statement: The study was conducted according to the guidelines of the Declaration of Helsinki, and approved by Ethics Committee of the Catholic University of Murcia (date: 24 November 2017; Code: CE111702).

Informed Consent Statement: Informed consent was obtained from all subjects involved in the study.

Acknowledgments: The authors want to thank the subjects for participating in the study. We would like to thank the juice plus company for the support and promotion of the research.

Conflicts of Interest: The authors declare do not have conflict of interest regarding the present manuscript.

\begin{tabular}{|c|c|}
\hline \\
\hline \multicolumn{2}{|c|}{$\begin{array}{l}\text { Abbreviations } \\
\text { The following abbreviations are used in this mant }\end{array}$} \\
\hline NO & nitric oxide \\
\hline ROS & reactive oxygen species \\
\hline MRI & magnetic resonance imaging \\
\hline RIAS & Reynolds Intellectual Assessment Scales \\
\hline RIST & Reynolds Intellectual Screening Test \\
\hline TS & typical scores \\
\hline RI & RIST Index \\
\hline SD & standard deviation \\
\hline TMT & trail making test \\
\hline RVIP & Rapid Visual Information Processing \\
\hline CREB & cAMP response element-binding \\
\hline
\end{tabular}

\section{References}

1. Battino, M.; Beekwilder, J.; Denoyes-Rothan, B.; Laimer, M.; McDougall, G.J.; Mezzetti, B. Bioactive compounds in berries relevant to human health. Nutr. Rev. 2009, 67, S145-S150. [CrossRef] [PubMed]

2. Skrovankova, S.; Sumczynski, D.; Mlcek, J.; Jurikova, T.; Sochor, J. Bioactive compounds and antioxidant activity in different types of berries. Int. J. Mol. Sci. 2015, 16, 24673-24706. [CrossRef] [PubMed]

3. Nile, S.H.; Park, S.W. Edible berries: Bioactive components and their effect on human health. Nutrition 2014, 30, 134-144. [CrossRef] [PubMed]

4. $\quad$ Péter, S.; Holguin, F.; Wood, L.G.; Clougherty, J.E.; Raederstorff, D.; Antal, M.; Weber, P.; Eggersdorfer, M. Nutritional solutions to reduce risks of negative health impacts of air pollution. Nutrients 2015, 7, 10398-10416. [CrossRef] [PubMed]

5. Francis, S.; Head, K.; Morris, P.; Macdonald, I. The effect of flavanol-rich cocoa on the fMRI response to a cognitive task in healthy young people. J. Cardiovasc. Pharmacol. 2006, 47, S215-S220. [CrossRef] [PubMed]

6. Swaab, D.F.; Bao, A.-M.; Lucassen, P.J. The stress system in the human brain in depression and neurodegeneration. Ageing Res. Rev. 2005, 4, 141-194. [CrossRef]

7. Bell, L.; Lamport, D.J.; Butler, L.T.; Williams, C.M. A review of the cognitive effects observed in humans following acute supplementation with flavonoids, and their associated mechanisms of action. Nutrients 2015, 7, 10290-10306. [CrossRef]

8. Wang, J.; Ferruzzi, M.G.; Ho, L.; Blount, J.; Janle, E.M.; Gong, B.; Pan, Y.; Gowda, G.N.; Raftery, D.; Arrieta-Cruz, I. Brain-targeted proanthocyanidin metabolites for Alzheimer's disease treatment. J. Neurosci. 2012, 32, 5144-5150. [CrossRef]

9. Wightman, E.L.; Haskell-Ramsay, C.F.; Reay, J.L.; Williamson, G.; Dew, T.; Zhang, W.; Kennedy, D.O. The effects of chronic trans-resveratrol supplementation on aspects of cognitive function, mood, sleep, health and cerebral blood flow in healthy, young humans. Br. J. Nutr. 2015, 114, 1427-1437. [CrossRef]

10. Hollman, P.C.; Cassidy, A.; Comte, B.; Heinonen, M.; Richelle, M.; Richling, E.; Serafini, M.; Scalbert, A.; Sies, H.; Vidry, S. The biological relevance of direct antioxidant effects of polyphenols for cardiovascular health in humans is not established. J. Nutr. 2011, 141, 989S-1009S. [CrossRef]

11. Lamport, D.J.; Lawton, C.L.; Merat, N.; Jamson, H.; Myrissa, K.; Hofman, D.; Chadwick, H.K.; Quadt, F.; Wightman, J.D.; Dye, L. Concord grape juice, cognitive function, and driving performance: A 12-wk, placebo-controlled, randomized crossover trial in mothers of preteen children. Am. J. Clin. Nutr. 2016, 103, 775-783. [CrossRef] [PubMed] 
12. Philip, P.; Sagaspe, P.; Taillard, J.; Mandon, C.; Constans, J.; Pourtau, L.; Pouchieu, C.; Angelino, D.; Mena, P.; Martini, D. Acute Intake of a Grape and Blueberry Polyphenol-Rich Extract Ameliorates Cognitive Performance in Healthy Young Adults During a Sustained Cognitive Effort. Antioxidants 2019, 8, 650. [CrossRef] [PubMed]

13. Miller, M.G.; Shukitt-Hale, B. Berry fruit enhances beneficial signaling in the brain. J. Agric. Food Chem. 2012, 60, 5709-5715. [CrossRef] [PubMed]

14. Joseph, J.A.; Shukitt-Hale, B.; Willis, L.M. Grape juice, berries, and walnuts affect brain aging and behavior. J. Nutr. 2009, 139, 1813S-1817S. [CrossRef]

15. Sarubbo, F.; Moranta, D.; Pani, G. Dietary polyphenols and neurogenesis: Molecular interactions and implication for brain ageing and cognition. Neurosci. Biobehav. Rev. 2018, 90, 456-470. [CrossRef]

16. Huhn, S.; Kharabian Masouleh, S.; Stumvoll, M.; Villringer, A.; Witte, A.V. Components of a Mediterranean diet and their impact on cognitive functions in aging. Front. Aging Neurosci. 2015, 7, 132. [CrossRef]

17. Best, T.; Clarke, C.; Nuzum, N.; Teo, W.-P. Acute effects of combined Bacopa, American ginseng and whole coffee fruit on working memory and cerebral haemodynamic response of the prefrontal cortex: A double-blind, placebo-controlled study. Nutr. Neurosci. 2019, 1-12. [CrossRef]

18. FÚart, C.; Samieri, C.; Rondeau, V.; Amieva, H.; Portet, F.; Dartigues, J.-F.; Scarmeas, N.; Barberger-Gateau, P. Adherence to a Mediterranean diet, cognitive decline, and risk of dementia. JAMA 2009, 302, 638-648. [CrossRef]

19. Pistollato, F.; Sumalla Cano, S.; Elio, I.; Masias Vergara, M.; Giampieri, F.; Battino, M. Associations between sleep, cortisol regulation, and diet: Possible implications for the risk of Alzheimer disease. Adv. Nutr. 2016, 7, 679-689. [CrossRef]

20. Lefèvre-Arbogast, S.; Gaudout, D.; Bensalem, J.; Letenneur, L.; Dartigues, J.-F.; Hejblum, B.P.; Féart, C.; Delcourt, C.; Samieri, C. Pattern of polyphenol intake and the long-term risk of dementia in older persons. Neurology 2018, 90, e1979-e1988. [CrossRef]

21. Allom, V.; Mullan, B. Individual differences in executive function predict distinct eating behaviours. Appetite 2014, 80, 123-130. [CrossRef]

22. Lamport, D.J.; Pal, D.; Macready, A.L.; Barbosa-Boucas, S.; Fletcher, J.M.; Williams, C.M.; Spencer, J.P.; Butler, L.T. The effects of flavanone-rich citrus juice on cognitive function and cerebral blood flow: An acute, randomised, placebo-controlled cross-over trial in healthy, young adults. Br. J. Nutr. 2016, 116, 2160-2168. [CrossRef] [PubMed]

23. De Jager, C.A.; Dye, L.; De Bruin, E.A.; Butler, L.; Fletcher, J.; Lamport, D.J.; Latulippe, M.E.; Spencer, J.P.; Wesnes, K. Criteria for validation and selection of cognitive tests for investigating the effects of foods and nutrients. Nutr. Rev. 2014, 72, 162-179. [CrossRef] [PubMed]

24. Gilsenan, M. Nutrition \& health claims in the European Union: A regulatory overview. Trends Food Sci. Technol. 2011, 22, 536-542.

25. Santos-Buelga, C.; González-Paramás, A.M.; Oludemi, T.; Ayuda-Durán, B.; González-Manzano, S. Plant phenolics as functional food ingredients. Adv. Food Nutr. Res. 2019, 90, 183-257. [PubMed]

26. Salehi, B.; Iriti, M.; Vitalini, S.; Antolak, H.; Pawlikowska, E.; Kręgiel, D.; Sharifi-Rad, J.; Oyeleye, S.I.; Ademiluyi, A.O.; Czopek, K. Euphorbia-Derived Natural Products with Potential for Use in Health Maintenance. Biomolecules 2019, 9, 337. [CrossRef] [PubMed]

27. Piccolella, S.; Crescente, G.; Candela, L.; Pacifico, S. Nutraceutical Polyphenols: New analytical challenges and opportunities. J. Pharm. Biomed. Anal. 2019, 175, 112774. [CrossRef]

28. Gildawie, K.R.; Galli, R.L.; Shukitt-Hale, B.; Carey, A.N. Protective effects of foods containing flavonoids on age-related cognitive decline. Curr. Nutr. Rep. 2018, 7, 39-48. [CrossRef]

29. Flanagan, E.; Müller, M.; Hornberger, M.; Vauzour, D. Impact of flavonoids on cellular and molecular mechanisms underlying age-related cognitive decline and neurodegeneration. Curr. Nutr. Rep. 2018, 7, 49-57. [CrossRef]

30. Lamport, D.J.; Saunders, C.; Butler, L.T.; Spencer, J.P. Fruits, vegetables, 100\% juices, and cognitive function. Nutr. Rev. 2014, 72, 774-789. [CrossRef]

31. Spencer, J.P. The impact of fruit flavonoids on memory and cognition. Br. J. Nutr. 2010, 104, S40-S47. [CrossRef] [PubMed]

32. Houghton, C.A. Sulforaphane: Its "Coming of Age" as a Clinically Relevant Nutraceutical in the Prevention and Treatment of Chronic Disease. Oxidative Med. Cell. Longev. 2019, 2019. [CrossRef] [PubMed]

33. Poddar, J.; Pradhan, M.; Ganguly, G.; Chakrabarti, S. Biochemical deficits and cognitive decline in brain aging: Intervention by dietary supplements. J. Chem. Neuroanat. 2019, 95, 70-80. [CrossRef] [PubMed]

34. Rendeiro, C.; Guerreiro, J.D.; Williams, C.M.; Spencer, J.P. Flavonoids as modulators of memory and learning: Molecular interactions resulting in behavioural effects. Proc. Nutr. Soc. 2012, 71, 246-262. [CrossRef] [PubMed]

35. Coultrap, S.J.; Bickford, P.C.; Browning, M.D. Blueberry-enriched diet ameliorates age-related declines in NMDA receptordependent LTP. Age 2008, 30, 263-272. [CrossRef] [PubMed]

36. Li, Q.; Zhao, H.; Zhang, Z.; Liu, Z.; Pei, X.; Wang, J.; Li, Y. Long-term green tea catechin administration prevents spatial learning and memory impairment in senescence-accelerated mouse prone- 8 mice by decreasing A $\beta 1-42$ oligomers and upregulating synaptic plasticity-related proteins in the hippocampus. Neuroscience 2009, 163, 741-749. [CrossRef]

37. Cohen-Salmon, C.; Venault, P.; Martin, B.; Raffalli-Sebille, M.; Barkats, M.; Clostre, F.; Pardon, M.; Christen, Y.; Chapouthier, G. Effects of Ginkgo biloba extract (EGb 761) on learning and possible actions on aging. J. Physiol. Paris 1997, 91, 291-300. [CrossRef]

38. Abellán Alemán, J.; Zafrilla Rentero, M.P.; Montoro-García, S.; Mulero, J.; Perez Garrido, A.; Leal, M.; Guerrero, L.; Ramos, E.; Ruilope, L.M. Adherence to the "Mediterranean diet" in Spain and its relationship with cardiovascular risk (DIMERICA study). Nutrients 2016, 8, 680. [CrossRef] 
39. Trichopoulou, A.; Costacou, T.; Bamia, C.; Trichopoulos, D. Adherence to a Mediterranean diet and survival in a Greek population. N. Engl. J. Med. 2003, 348, 2599-2608. [CrossRef]

40. Bresciani, L.; Martini, D.; Mena, P.; Tassotti, M.; Calani, L.; Brigati, G.; Brighenti, F.; Holasek, S.; Malliga, D.-E.; Lamprecht, M. Absorption profile of (poly) phenolic compounds after consumption of three food supplements containing 36 different fruits, vegetables, and berries. Nutrients 2017, 9, 194. [CrossRef]

41. Novembrino, C.; Cighetti, G.; De Giuseppe, R.; Vigna, L.; de Liso, F.; Pellegatta, M.; Gregori, D.; Maiavacca, R.; Bamonti, F. Effects of encapsulated fruit and vegetable juice powder concentrates on oxidative status in heavy smokers. J. Am. Coll. Nutr. 2011, 30, 49-56. [CrossRef] [PubMed]

42. Chapple, I.L.; Milward, M.R.; Ling-Mountford, N.; Weston, P.; Carter, K.; Askey, K.; Dallal, G.E.; De Spirt, S.; Sies, H.; Patel, D. Adjunctive daily supplementation with encapsulated fruit, vegetable and berry juice powder concentrates and clinical periodontal outcomes: A double-blind RCT. J. Clin. Periodontol. 2012, 39, 62-72. [CrossRef] [PubMed]

43. Lamprecht, M.; Oettl, K.; Schwaberger, G.; Hofmann, P.; Greilberger, J.F. Several indicators of oxidative stress, immunity, and illness improved in trained men consuming an encapsulated juice powder concentrate for 28 weeks. J. Nutr. 2007, 137, 2737-2741. [CrossRef] [PubMed]

44. Golden, C.J. Stroop Color and Word Test: A Manual for Clinical and Experimental Uses; Stoelting: Chicago, IL, USA, 1978.

45. Zhu, N.; Jacobs, D.R.; Meyer, K.; He, K.; Launer, L.; Reis, J.; Yaffe, K.; Sidney, S.; Whitmer, R.; Steffen, L. Cognitive function in a middle aged cohort is related to higher quality dietary pattern 5 and 25 years earlier: The CARDIA study. J. Nutr. Health Aging 2015, 19, 33-38. [CrossRef]

46. Carillon, J.; Notin, C.; Schmitt, K.; Simoneau, G.; Lacan, D. Dietary supplementation with a superoxide dismutase-melon concentrate reduces stress, physical and mental fatigue in healthy people: A randomised, double-blind, placebo-controlled trial. Nutrients 2014, 6, 2348-2359. [CrossRef]

47. Whyte, A.R.; Williams, C.M. Effects of a single dose of a flavonoid-rich blueberry drink on memory in 8 to $10 \mathrm{y}$ old children. Nutrition 2015, 31, 531-534. [CrossRef]

48. Macready, A.L.; Butler, L.T.; Kennedy, O.B.; Ellis, J.A.; Williams, C.M.; Spencer, J.P. Cognitive tests used in chronic adult human randomised controlled trial micronutrient and phytochemical intervention studies. Nutr. Res. Rev. 2010, 23, 200-229. [CrossRef]

49. Portellano, J.; Martínez Arias, R.T. Test de los Senderos; TEA Ediciones: Madrid, Spain, 2014.

50. Raines, T.C.; Reynolds, C.R.; Kamphaus, R.W. The Reynolds Intellectual Assessment Scales, and the Reynolds Intellectual Screening Test; Psychological Assessment Resources Inc.: Lutz, FL, USA, 2018.

51. Greve, A.; Jepsen, J.R.M.; Mortensen, E.L.; Uher, R.; Mackenzie, L.; Foldager, L.; Gantriis, D.; Burton, B.K.; Ellersgaard, D.; Christiani, C.J. F84. associations between intelligence, verbal working memory and processing speed in parents with schizophrenia or bipolar disorder and their 7-year old offspring. Schizophr. Bull. 2018, 44, S252. [CrossRef]

52. Lee, J.; Torosyan, N.; Silverman, D.H. Examining the impact of grape consumption on brain metabolism and cognitive function in patients with mild decline in cognition: A double-blinded placebo controlled pilot study. Exp. Gerontol. 2017, 87, 121-128. [CrossRef]

53. Wightman, E.L.; Jackson, P.A.; Khan, J.; Forster, J.; Heiner, F.; Feistel, B.; Suarez, C.G.; Pischel, I.; Kennedy, D.O. The Acute and Chronic Cognitive and Cerebral Blood Flow Effects of a Sideritis scardica (Greek Mountain Tea) Extract: A Double Blind, Randomized, Placebo Controlled, Parallel Groups Study in Healthy Humans. Nutrients 2018, 10, 955. [CrossRef]

54. Travica, N.; D’Cunha, N.M.; Naumovski, N.; Kent, K.; Mellor, D.D.; Firth, J.; Georgousopoulou, E.N.; Dean, O.M.; Loughman, A.; Jacka, F. The effect of blueberry interventions on cognitive performance and mood: A systematic review of randomized controlled trials. Brain Behav. Immun. 2019, 85, 96-105. [CrossRef] [PubMed]

55. Herrlinger, K.A.; Chirouzes, D.M.; Ceddia, M.A. Supplementation with a polyphenolic blend improves post-exercise strength recovery and muscle soreness. Food Nutr. Res. 2015, 59, 30034. [CrossRef] [PubMed]

56. Bowtell, J.L.; Aboo-Bakkar, Z.; Conway, M.E.; Adlam, A.-L.R.; Fulford, J. Enhanced task-related brain activation and resting perfusion in healthy older adults after chronic blueberry supplementation. Appl. Physiol. Nutr. Metab. 2017, 42, 773-779. [CrossRef] [PubMed]

57. Gleason, C.E.; Carlsson, C.M.; Barnet, J.H.; Meade, S.A.; Setchell, K.D.; Atwood, C.S.; Johnson, S.C.; Ries, M.L.; Asthana, S. A preliminary study of the safety, feasibility and cognitive efficacy of soy isoflavone supplements in older men and women. Age Ageing 2009, 38, 86-93. [CrossRef] [PubMed]

58. Mix, J.A.; Crews, W.D., Jr. An examination of the efficacy of Ginkgo biloba extract EGb 761 on the neuropsychologic functioning of cognitively intact older adults. J. Altern. Complement. Med. 2000, 6, 219-229. [CrossRef] [PubMed]

59. Gyorkos, A.; Baker, M.H.; Miutz, L.N.; Lown, D.A.; Jones, M.A.; Houghton-Rahrig, L.D. Carbohydrate-restricted Diet and Exercise Increase Brain-derived Neurotrophic Factor and Cognitive Function: A Randomized Crossover Trial. Cureus $2019,11$. [CrossRef]

60. Rabassa, M.; Cherubini, A.; Zamora-Ros, R.; Urpi-Sarda, M.; Bandinelli, S.; Ferrucci, L.; Andres-Lacueva, C. Low Levels of a Urinary Biomarker of Dietary Polyphenol Are Associated with Substantial Cognitive Decline over a 3-Year Period in Older Adults: The Invecchiare in Chianti Study. J. Am. Geriatr. Soc. 2015, 63, 938-946. [CrossRef]

61. Nurk, E.; Refsum, H.; Drevon, C.A.; Tell, G.S.; Nygaard, H.A.; Engedal, K.; Smith, A.D. Intake of flavonoid-rich wine, tea, and chocolate by elderly men and women is associated with better cognitive test performance. J. Nutr. 2009, 139, 120-127. [CrossRef] 
62. Nilsson, A.; Salo, I.; Plaza, M.; Björck, I. Effects of a mixed berry beverage on cognitive functions and cardiometabolic risk markers; A randomized cross-over study in healthy older adults. PLoS ONE 2017, 12, e0188173. [CrossRef]

63. Riaz, A.; Khan, R.A.; Algahtani, H.A. Memory boosting effect of Citrus limon, Pomegranate and their combinations. Pak. J. Pharm. Sci. 2014, 27, 1837-1840.

64. Williams, C.M.; Abd El Mohsen, M.; Vauzour, D.; Rendeiro, C.; Butler, L.T.; Ellis, J.A.; Whiteman, M.; Spencer, J.P. Blueberryinduced changes in spatial working memory correlate with changes in hippocampal CREB phosphorylation and brain-derived neurotrophic factor (BDNF) levels. Free Radic. Biol. Med. 2008, 45, 295-305. [CrossRef] [PubMed]

65. Van Praag, H.; Lucero, M.J.; Yeo, G.W.; Stecker, K.; Heivand, N.; Zhao, C.; Yip, E.; Afanador, M.; Schroeter, H.; Hammerstone, J. Plant-derived flavanol (-) epicatechin enhances angiogenesis and retention of spatial memory in mice. J. Neurosci. 2007, 27, 5869-5878. [CrossRef] [PubMed]

66. Drouin, A.; Bolduc, V.; Thorin-Trescases, N.; Bélanger, É.; Fernandes, P.; Baraghis, E.; Lesage, F.; Gillis, M.-A.; Villeneuve, L.; Hamel, E. Catechin treatment improves cerebrovascular flow-mediated dilation and learning abilities in atherosclerotic mice. Am. J. Physiol. Heart Circ. Physiol. 2011, 300, H1032-H1043. [CrossRef]

67. Bisson, J.-F.; Nejdi, A.; Rozan, P.; Hidalgo, S.; Lalonde, R.; Messaoudi, M. Effects of long-term administration of a cocoa polyphenolic extract (Acticoa powder) on cognitive performances in aged rats. Br. J. Nutr. 2008, 100, 94-101. [CrossRef] [PubMed] 